\begin{tabular}{c} 
Volume and Issues Obtainable at Center for Sustainability Research and Consultancy \\
Journal of Business and Social Review in Emerging Economies \\
ISSN: 2519-089X \& (E): 2519-0326 \\
Volume 7: No. 1, March 2021 \\
JSRᄃ \\
Journal homepage: www.publishing.globalcsrc.org/jbsee \\
\hline
\end{tabular}

\title{
Impact of Soap Operas on the Television Viewers: Experience from Pakistani Society
}

*Beenish Zaheen, Lecturer, Department of Mass Communication, The Women University Multan, Punjab, Pakistan

Aasima Safdar, Communication Studies Department, Bahauddin Zakariya University, Multan, Pakistan Muhammad Riaz, Lecturer, Riphah Institute of Media Sciences, Riphah International University, Pakistan

*Corresponding author's email address: aasima.2014@gmail.com

ARTICLE DETAILS ABSTRACT

\section{History}

Revised format: Feb 2021

Available Online: Mar 2021

Keywords

Soap operas, Star plus dramas, Cultivation analysis, Women portrayal, Women

empowerment

JEL Classification:

$M 0, M 1$
Purpose: Soap operas are popular genre in media industry from all over the world. Generally, Soap operas focus on family dramas, domestic issues and women plight. There were number of studies conducted to explore public perception regarding soap operas. The present study aimed to explore the opinion from Pakistani society regarding their experience of watching Star plus soap operas. Design/Methodology/Approach: The research based on Cultivation theoretical framework which intended to explore the difference between heavy and light viewers of Star plus soap operas. Research design is quantitative. Survey method is utilized to collect data from the respondents. Findings: The results showed that there was no significant difference exist between heavy and light viewers perception. Both type of viewers supported females' educational, political and legal rights in the society. The time spent in watching Star Plus soap operas did not have great impact on heavy viewers in changing their minds and thoughts. Implications/Originality/Value: It is a unique study using survey method to gauge the opinion of heavy and light viewers of star plus soap operas. It will be very useful for other researchers who are interested in studying the impact of television in the lives of people. It will provide them with an excellent insight about the factors that mediate the cultivation process.

(C) 2021 The authors, under a Creative Commons AttributionNonCommercial 4.0

Recommended citation: Zaheen, B., Safdar, A. \& Riaz, M. (2021). Impact of Soap Operas on the Television viewers: Experience from Pakistani society. Journal of Business and Social Review in Emerging Economies, 7(1), 45-56

\section{Introduction}

Soap operas have gained much popularity in all over the world. Due to this genre the television ruled media industry locally and globally. Soap operas generally focused on female issues and problems. It 
was explored in the developing countries that females were mostly projected in oppressed manner in television programmes, dramas and soap operas. In developing countries women are most oppressed segment of the society. Men do not like to discuss the matters relating to women's rights. They are facing discrimination on economic, social, political and moral grounds. Although there were several remedies suggested for women relating to their equal rights, opportunities and employment but it did not led to substantial benefits for them (Ahmed, 1991).

Particularly, during ancient times, women were given very limited rights in Indian community. After husband death, they were forced to commit Sati or to have perennial solitude. Now the situation has been changed. But still Indian women are suffering from many disabilities and social injustices. In this regard, Indian media played its role to uplift the status of women in their society. Similarly, Indian government and civil society also made their contribution in this regard. However, it is assumed that women empowerment is always a part of development agenda. There is close relationship between development and empowerment. Development refers to increase in GNP or per capita income of some country.

In this regard, electronic media can create awareness in society relating to women rights, injustices against women and the formation of women protection laws. Moreover, the women can also be educated that how they can protect themselves. Media can play positive role in reflecting positive image of females in society and change the damaging stereotypes. Women in Pakistan particularly experience discrimination since their childhood. No body celebrates their birth, they are given left over food, they are not educated on priority basis and they are handed over in marriage without their consent. At time, the women serve as a good commodity to be donated in return for a crime committed by her brother, fathers or uncles and sometimes exchanged to bring a beautiful bride for these relations. Moreover despite being legally declared as murder, the Karo Kari Law is not yet implemented. But in present scenario Pakistani civil society, media and government played substantial role to uplift the status of women and certain women protection laws are also formed to protect women rights in Pakistan.

As far as media is concerned in Pakistan, both Indian and Pakistani dramas are quite popular. From Indian media the people preferred to watch Star plus soap operas. The present study aimed to explore the opinion of the viewers of star plus soap operas and investigated the effects that had been created on the minds of the people by these dramas. The current research study mainly focuses on the following aspects.

- While considering the large viewer ship of Star Plus soap operas in Pakistan, the study investigates the influences of Star Plus soap operas on the minds of adults from Multan and bringing about change in their thoughts regarding women empowerment.

- The study tries to analyze how the Star Plus soap operas have an impact on the minds of heavy viewers, lights viewers, male viewers and female viewers differently.

\section{Literature Review}

The previous researchers noted that the women were mostly framed in passive characters but few mentioned that they were projected in strong roles as well. It was noted that the presentation of females in prime time programmes are quite positive and they were presented as successful and strong characters (Sephlow, 1999, P. 302, as cited in Wood). However, Brown, Cambell \& Fisher (as cited in Wood, 1999, P. 307) analyze MTV programmes and reveal that women is portrayed by MTV as passive, waiting for the attention of men where as men are portrayed as exploiter, ignoring and directing women.

Brown's study (as cited in Thornham, 2000, P.113) explains that the texts of soap operas are hegemonic. These are mainly designed to reinforce the dominant conceptualization of women. Furthermore she argues that much of women's pleasure in soap operas comes through feminine gossip. Her research is 
based on the work of Hall and Morley. On the other hand, Harnois (2005) discussed generational differences within contemporary American feminism. The researcher identifies three dominant approaches for understanding 'third wave' feminism which are cohet-based, age-based and theory based. The findings suggest that feminist of all ages share many important aspects of their gender and political ideologies.

Nihal Singh (as cited in Kumar \& Varghese, 2005, P. 60) studies the main areas of women development such as economic sector, law, security of family and property and equal opportunities in educational and employment sector. The main focus of his study is on all kinds of developmental parameters to bring women into mainstream development. However, it was noted from Indian media perspective, women were projected in passive, obedient and weak characters. That can be convinced and managed easily. It was argued that women empowerment must be promoted through media. Women must be shown in strong characters that can diminish the stereotype images of the females from the society (Kumar \& Varghese, 2005).

Wrye (2009) uses psychoanalytic perspective to trace 4 ways of feminism. The first phase which focused on women's right to vote. The second phase located in 1960's and 1970's, in which peoples' consciousness about gender issues was raised. Third phase evolved in 1980's and 1990's focused more on sexual freedom and job opportunities. It mainly stressed on gender pluralities. The fourth wave of feminism evolved in $21^{\text {st }}$ century. During this era the women turned towards spirituality, engaged themselves in the service of nature, world and oppressed.

Shoma (2009) described in her book that Soap operas of Indian television discussed the social issues, problems and practices of their society. They focused on the issues related to family, values and gender. Karaj (2000) observed that the women in television Soap operas were mainly projected as young, beautiful, unmarried and professionals. Such type of depiction did not show the real picture of the society and women felt dissatisfied with their lives. Contrary to this, Kaul and Sahni (2010) investigated the effects of TV serials on the society regarding the projection of Indian Women in media. The respondents argued that they got confidence and learned how to manage their domestic life.

Whereas, Brown's study (as cited in Thornham, 2000, P.113) suggested that Indian soap operas are mainly designed to reinforce the dominant conceptualization of women. Furthermore she argues that much of women's pleasure in soap operas comes through feminine gossip. However, Aslam (2006) studied the impact of Indian dramas on cultural values of the society. It was observed that during Pakistani wedding, there were certain customs performed that did not belong to Pakistani culture. Because such ceremonies were shown by Indian dramas, so that the exposure to such content influenced the Pakistani society (Aslam, 2006).

On the other hand, Shabir, Safdar and Imran (2013) studied the impact of Pakistani dramas on viewers. It was observed that Pakistani females adopted fashion styles of celebrities and popular models that were shown on GEO and HUM TV. Likewise, Rahim (1994) studied that the effect of television on the lifestyles of Pakistani women. It was noted that there was change in social behavior, cooking patterns, dressing styles, outlook, appearance and language of the viewers. From foreign media perspective, it was observed that the foreign media had influenced the Pakistani culture and particularly the Indian television soap operas. Such media content influenced nature of social relationships and life style of the society. Even Pakistani dramas show star plus culture in their stories. Such type of TV content influencing our values and causing domestic problems (Mahvish, 2006: Mustafa, 2006).From Western media perspective, Brown, Cambell \& Fisher (as cited in Wood, 1999, P. 307) noted that women were projected in MTV programmes as passive, exploiter and directive women who were always waiting for men attention.

The previous literature suggested that exposure to media content influence the perception of its viewers. 
The present study explored that to what the exposure to Indian soap operas influenced the opinion of viewers regarding the rights of the females. And what difference exists between heavy and light viewers' perception.

\section{Theoretical Framework}

Cultivation theory was used as the theoretical framework for this study. George Gerbner was the founder of the theory. He presented his idea in 1979. It was argued that media had strong influence on the perceptions of television viewers regarding the environment of outside world. If media gave repeated exposure to the particular content, issues or people, it affected public perception about social reality (Bryant \& Thompson, 2002, p.101-102).

Moreover Cultivation Theory by George Gerbner is used as a guide to analyze the effects and consequences of watching Star Plus soap operas. The cultivation theory asserts that heavy viewers' attitudes are cultivated primarily by what they watch on television. Moreover television is mainly responsible for shaping viewers conception of social reality. Cultivation theorists were of the view that television drama has small but significant influence on attitudes, believes and judgment of viewers concerning the social world. The study focused on cultivation theory to measure cultivation perception of Star Plus soap operas viewers regarding feministic ideology and women empowerment. On the basis of above mentioned literature the following research question and hypothesis were formulated.

RQ: What is the difference in the impact of cultivation of feministic ideology on the minds of heavy viewers and light viewers regarding women empowerment?

H1: The heavy viewers of Star Plus soap operas will be more in favour of women's participation in national decision making process than light viewers.

H2: The heavy viewers of Star Plus soaps operas will be more in favour of women's equal educational rights than the light viewers.

H3: The heavy viewers of Star Plus soap operas will be more in favour of government formulation of laws to protect women against violence than the light viewers.

\section{Method}

This study chooses survey method to study the impact of Star Plus soap operas on the behavior and beliefs of viewers from Multan. The entire citizens of Multan are considered as the population of the study and a sample of 200 respondents (Star Plus viewers) having an age between 20-45 is drawn-out of the population by employing purposive sampling technique. The sample was divided into four groups;
- 50 male light viewers
- 50 female light viewers
- 50 male heavy viewers
- 50 female heavy viewers

\section{Findings}

In finding section, the data was presented in form figures and tables. After collecting all the data, the researcher has presented it in the form of table and figures. The analysis of data obtained from survey method is presented in time wise analysis of data, presenting the responses of heavy viewers and light viewers regarding women empowerment.

Table No. 1.1: Views about Women's Right to Participate in Household Decision 


\begin{tabular}{llllll}
\multirow{2}{*}{ Responses } & \multicolumn{2}{l}{ Respondents } & & \\
& $\mathrm{N}$ & $\%$ & $\mathrm{~N}$ & $\%$ & \\
\hline Agree & 80 & 80 & 89 & 89 & 169 \\
Disagree & 17 & 17 & 9 & 9 & 26 \\
No opinion & 3 & 3 & 2 & 2 & 5 \\
\hline Total & 100 & 100 & 100 & 100 & 200
\end{tabular}

Table no. 1.1 shows that $80 \%$ light viewers and $89 \%$ heavy viewers agreed that women should be given equal rights as that of men to participate in major household decisions whereas $17 \%$ light viewers and $9 \%$ in case of heavy viewers didn't agree to it. Moreover $3 \%$ light viewers and $2 \%$ heavy viewers gave no opinion.

Table No. 1.2: Views about Seeking Girl's Consent about her Life Partner

\begin{tabular}{llllll} 
Responses & Light viewers & \multicolumn{2}{c}{ Heavy viewers } & Total \\
& $\mathrm{N}$ & $\%$ & $\mathrm{~N}$ & $\%$ & \\
\hline Yes & 83 & 83 & 85 & 85 & 168 \\
Up to some extent & 9 & 9 & 3 & 3 & 12 \\
No & 8 & 8 & 12 & 12 & 20 \\
\hline Total & 100 & 100 & 100 & 100 & 200
\end{tabular}

Table no. 1.2 shows that $85 \%$ heavy viewers and $83 \%$ light viewers believed that it is important to seek girl's opinion in selecting her life partner whereas $8 \%$ light viewers and $12 \%$ in case of heavy viewers did not consider it important to seek girl's opinion in selecting her life partner. Moreover 9\% light viewers and $3 \%$ heavy viewers considered it important up to some extent.

Table No. 1.3: Views about Women's Equal Right to Cast Vote

\begin{tabular}{llllll} 
& \multicolumn{2}{l}{ Respondents } & & & \\
Light viewers & & Heavy viewers & Total \\
Responses & $\mathrm{N}$ & $\%$ & $\mathrm{~N}$ & $\%$ & \\
\hline Yes & 86 & 86 & 84 & 84 & 170 \\
No & 10 & 10 & 10 & 10 & 20 \\
No Opinion & 4 & 4 & 6 & 6 & 10 \\
\hline Total & 100 & 100 & 100 & 100 & 200
\end{tabular}

Table no. 1.3 reveals that $84 \%$ heavy viewers and $86 \%$ light viewers believed that women should be given equal rights to cast vote whereas $10 \%$ light viewers and $10 \%$ in case of heavy viewers opined that women should not be given equal right to cast vote. Moreover $4 \%$ light viewers and $6 \%$ heavy viewers gave no opinion.

Table No. 1.4: Views about Women's Equal Political Rights

\begin{tabular}{llllll} 
& \multicolumn{2}{l}{$\begin{array}{l}\text { Respondents } \\
\text { Light viewers }\end{array}$} & & Heavy viewers & \\
Responses & $\mathrm{N}$ & $\%$ & $\mathrm{~N}$ & $\%$ & \\
\hline Agree & 59 & 59 & 62 & 62 & 121 \\
Disagree & 35 & 35 & 31 & 31 & 66 \\
\hline
\end{tabular}




\begin{tabular}{llllll}
\hline No opinion & 6 & 6 & 7 & 7 & 13 \\
\hline Total & 100 & 100 & 100 & 100 & 200
\end{tabular}

Table no. 1.4 reveals that $62 \%$ heavy viewers and $59 \%$ light viewers agreed that that parliament should increase the number of special seats for women so that they can get equal chance to participate in politics whereas 35\% light viewers and $31 \%$ heavy viewers did not agree to it. Moreover $6 \%$ light viewers and $7 \%$ heavy viewers gave no opinion

Table No. 1.5: Views about Women's Equal Educational Rights

\begin{tabular}{llllll} 
& \multicolumn{2}{l}{ Respondents } & & & \\
& Light viewers & & Heavy viewers & & Total \\
Responses & $\mathrm{N}$ & $\%$ & $\mathrm{~N}$ & $\%$ & \\
\hline Agree & 92 & 92 & 90 & 90 & 182 \\
Disagree & 4 & 4 & 5 & 5 & 9 \\
No opinion & 4 & 4 & 5 & 5 & 9 \\
\hline Total & 100 & 100 & 100 & 100 & 200
\end{tabular}

Table no.1.5 reveals that $90 \%$ heavy viewers and \% 92 light viewers believed that women should be given equal opportunities as that of men to get maximum education whereas $4 \%$ light viewers and $5 \%$ heavy viewers opined that women should not be given equal opportunities as that of men to get maximum education. Moreover 4\% light viewers and 5\% heavy viewers gave no opinion.

Table No. 1.6: Views about Main Cause of Women's Suffering

\begin{tabular}{|c|c|c|c|c|c|}
\hline \multirow{3}{*}{ Responses } & \multicolumn{4}{|c|}{ Respondents } & \multirow{3}{*}{ Tota } \\
\hline & \multicolumn{2}{|c|}{ Light viewers } & \multicolumn{2}{|c|}{ Heavy viewers } & \\
\hline & $\mathrm{N}$ & $\%$ & $\mathrm{~N}$ & $\%$ & \\
\hline $\begin{array}{l}\text { Subordination of women and } \\
\text { prevailing system of rule of } \\
\text { men }\end{array}$ & 37 & 37 & 56 & 56 & 93 \\
\hline Social restrictions & 29 & 29 & 29 & 29 & 58 \\
\hline $\begin{array}{l}\text { Woman's misuse of liberty } \\
\text { provided to her }\end{array}$ & 34 & 34 & 15 & 15 & 49 \\
\hline Total & 100 & 100 & 100 & 100 & 200 \\
\hline
\end{tabular}

Table no. 1.6 reveals that $56 \%$ heavy viewers and $37 \%$ light viewers believed that subordination of women and prevailing system of rule of men is the main cause of women's sufferings in our society whereas $29 \%$ light viewers and $29 \%$ in case of heavy viewers opined that social restrictions are main cause of it. Moreover 34\% light viewers and $15 \%$ heavy viewers felt that women suffer due to the misuse of liberty provided to her.

Table No. 1.7: Views about Portrayal of Women as Assertive and Capable of Decision Making

\begin{tabular}{llllll} 
Responses & \multicolumn{2}{l}{ Respondents } & \multicolumn{2}{l}{ Total } \\
& Light viewers & \multicolumn{2}{l}{ Heavy viewers } & \\
& $\mathrm{N}$ & $\%$ & $\mathrm{~N}$ & $\%$ & \\
\hline No & 38 & 38 & 22 & 22 & 60 \\
Yes & 41 & 41 & 67 & 67 & 108 \\
Up to some extent & 21 & 21 & 11 & 11 & 32 \\
\hline Total & 100 & 100 & 100 & 100 & 200
\end{tabular}


Table no. 1.7 reveals that $67 \%$ heavy viewers and $41 \%$ light viewers supported the Star Plus portrayal of women character as assertive and capable of decision making. Whereas $38 \%$ light viewers and $22 \%$ heavy viewers did not support this. Moreover $21 \%$ light viewers and $11 \%$ heavy viewers supported it up to some extent.

Table No. 1.8: Views about Opinion and Experience of Male/Female Members of Family

Respondents

Light viewers Heavy viewers $\quad$ Total

\begin{tabular}{llllll} 
Responses & N & $\%$ & N & $\%$ & \\
\hline No & 15 & 15 & 13 & 13 & 28 \\
Yes & 68 & 68 & 64 & 64 & 132 \\
Up to some extent & 17 & 17 & 23 & 23 & 40 \\
\hline Total & 100 & 100 & 100 & 100 & 200
\end{tabular}

Table no. 1.8 reveals that $64 \%$ heavy viewers and $68 \%$ light viewers respondents believed that the opinion and experience of male members of family carry more weight than the female members whereas $15 \%$ light viewers and 13\% in case of heavy viewers didn't agree to it. Moreover $17 \%$ light viewers and $23 \%$ heavy viewers believed that up to some extent the experience of male members carry more weight than the female members.

Table No. 1.9: Views about Restricting Women to Home for Household Tasks Respondents

\begin{tabular}{llllll} 
Responses & Light viewers & & Heavy viewers & Total \\
& $\mathrm{N}$ & $\%$ & $\mathrm{~N}$ & $\%$ & \\
\hline Yes & 38 & 38 & 44 & 44 & 82 \\
No & 55 & 55 & 51 & 51 & 106 \\
No opinion & 7 & 7 & 5 & 5 & 12 \\
\hline Total & 100 & 100 & 100 & 100 & 200
\end{tabular}

Table no. 1.9 reveals that $51 \%$ heavy viewers and 55\% light viewers believed that women should not be confined to home for performing household task whereas $38 \%$ light viewers and $44 \%$ in case of heavy viewers opined that women should be confined to home for household task. Moreover $7 \%$ light viewers and $5 \%$ heavy viewers gave no opinion.

Table No. 1.10: Views of Women's Respondents Getting Equal Rights at Workplace Respondents

\begin{tabular}{llllll} 
Responses & Light viewers & \multicolumn{2}{l}{ Heavy viewers } & Total \\
& $\mathrm{N}$ & $\%$ & $\mathrm{~N}$ & $\%$ & \\
\hline Yes & 47 & 47 & 44 & 44 & 91 \\
No & 32 & 32 & 12 & 12 & 44 \\
No opinion & 21 & 21 & 44 & 44 & 65 \\
\hline Total & 100 & 100 & 100 & 100 & 200
\end{tabular}

Table no. 1.10 reveals that $44 \%$ heavy viewers and $47 \%$ light viewers agreed that women working in their organization get equal pay and opportunities to that of men whereas $32 \%$ light viewers and $12 \%$ heavy viewers opined that in their organization women are not getting equal pay and opportunities. Moreover $21 \%$ light viewers and $44 \%$ heavy viewers gave no opinion.

Table No. 1.11: Views about Men's Responsibility to Help in Household Tasks 


\begin{tabular}{llllll} 
Responses & \multicolumn{2}{l}{ Light viewers } & Heavy viewers & \\
& $\mathrm{N}$ & $\%$ & $\mathrm{~N}$ & $\%$ & \\
\hline Agree & 69 & 69 & 67 & 67 & 136 \\
Disagree & 27 & 27 & 30 & 30 & 57 \\
No opinion & 4 & 4 & 3 & 3 & 7 \\
\hline Total & 100 & 100 & 100 & 100 & 200
\end{tabular}

Table no. 1.11 reveals that $67 \%$ heavy viewers and $69 \%$ light viewers agreed that the working hours of men should be reduced so that they can help their partners in nurturing kids and doing household tasks whereas $27 \%$ light viewers and 30\% heavy viewers did not agree to it. Moreover $4 \%$ light viewers and $3 \%$ heavy viewers gave no opinion.

Table No. 1.12: Views about the Best Remedy to Stop Violence

\begin{tabular}{|c|c|c|c|c|c|}
\hline \multirow{3}{*}{ Responses } & \multicolumn{5}{|c|}{ Respondents } \\
\hline & \multicolumn{2}{|c|}{ Light viewers } & \multicolumn{2}{|c|}{ Heavy viewers } & \multirow[t]{2}{*}{ Total } \\
\hline & $\mathrm{N}$ & $\%$ & $\mathrm{~N}$ & $\%$ & \\
\hline \multicolumn{6}{|l|}{$\begin{array}{l}\text { a. Women Rights Organization need to be proactive to } \\
\text { identify and stop the violence against women }\end{array}$} \\
\hline & 10 & 10 & 11 & 11 & 21 \\
\hline \multicolumn{6}{|l|}{ b. Government should formulate more laws to protect women } \\
\hline from violence & 79 & 79 & 81 & 81 & 160 \\
\hline \multicolumn{6}{|l|}{ c. women should come out of their houses to protest } \\
\hline & 11 & 11 & 8 & 8 & 19 \\
\hline Total & 100 & 100 & 100 & 100 & 200 \\
\hline
\end{tabular}

Table no. 1.12 reveals that $11 \%$ heavy viewers and $10 \%$ light viewers believed that women rights organization need to be proactive to identify and stop the violence against women. $79 \%$ light viewers and $81 \%$ heavy viewers opined that government should formulate more laws to protect women from violence. Moreover $11 \%$ light viewers and $8 \%$ heavy viewers opined that women should come out of their houses to protest.

Table No. 1.13: Views about Honour Killing

\begin{tabular}{llllll} 
& \multicolumn{2}{l}{ Respondents } & & \\
Responses & \multicolumn{2}{l}{ Light viewers } & Heavy viewers & Total \\
& $\mathrm{N}$ & $\%$ & $\mathrm{~N}$ & $\%$ & \\
\hline This ritual should be condemned and must be stopped & 88 & 88 & 81 & 81 & 169 \\
The way to punish disloyal and immoral woman & 3 & 3 & 9 & 9 & 12 \\
No opinion & 9 & 9 & 10 & 10 & 19 \\
\hline Total & 100 & 100 & 100 & 100 & 200
\end{tabular}

Table no. 1.13 shows that $81 \%$ heavy viewers and $88 \%$ light viewers believed that honour killing should be condemned. $3 \%$ light viewers and $9 \%$ heavy viewers opined that honour killing is the way to punish disloyal and immoral women whereas $9 \%$ light viewers and $10 \%$ heavy viewers gave no opinion.

Table No. 1.14: Expectation of Respondents from Media Regarding Image of Women 


\begin{tabular}{llllll} 
& \multicolumn{2}{l}{ Respondents } & & \\
Responses & \multicolumn{2}{l}{ Light viewers } & \multicolumn{2}{l}{ Heavy viewers } & Total \\
& $\mathrm{N}$ & $\%$ & $\mathrm{~N}$ & $\%$ & \\
\hline a. Wife/Mother/sister/Daughter/Daughter-in-law (stereotype & 29 & 29 & 25 & 25 & 54 \\
sex role performing household tasks) & 71 & 71 & 73 & 73 & 144 \\
b. Educated / Assertive & 0 & 0 & 2 & 2 & 2 \\
c. Un-Educated / Submissive & 0 & 0 & 0 & 0 & 0 \\
d. Sexual object & 100 & 100 & 100 & 100 & 200
\end{tabular}

Table no. 1.14 reveals that $25 \%$ heavy viewers and $29 \%$ light viewers believed that media should portray women in stereotyped sex roles whereas $71 \%$ light viewers and $73 \%$ heavy viewers opined that women should be portrayed as educated and assertive. $0 \%$ light viewers and $2 \%$ heavy viewers believed that media should portray women as uneducated and submissive. Moreover no one opined in favour of portrayal of woman character as sexual object.

Table No. 1.15: Role of Star Plus in Making Women Assertive

\begin{tabular}{llllll} 
& \multicolumn{2}{l}{ Respondents } & & & \\
Responses & Light Viewers & Heavy viewers & & Total \\
& $\mathrm{N}$ & $\%$ & $\mathrm{~N}$ & $\%$ & \\
\hline Yes & 74 & 74 & 77 & 77 & 151 \\
No & 18 & 18 & 16 & 16 & 34 \\
No opinion & 8 & 8 & 7 & 7 & 15 \\
\hline Total & 100 & 100 & 100 & 100 & 200
\end{tabular}

Table no. 1.15 reveals that $77 \%$ heavy viewers and $74 \%$ light viewers agreed that viewership of Star Plus soap operas has made women assertive whereas 18\% light viewers and $16 \%$ heavy viewers didn't agree to it .Moreover $8 \%$ light viewers and $7 \%$ heavy viewers gave no opinion.

\section{Discussion}

The present research analyzed the perception of population from Multan regarding their experience of watching Star Plus soap operas. The particular study was conducted in the light of cultivation theory. The time spent in watching Star Plus soaps was considered to be the most important variable according to the need of study. It was found that Star Plus soap operas did not have significant impact in changing the minds and thoughts of heavy viewers regarding women empowerment.

A vast majority of light viewers were of the view that men should never influence women's decisions regarding voting for particular party or a candidate. Light viewers were also more in favour of giving women equal rights to cast vote and to get maximum education than the heavy viewers. In the same way majority of light viewers were more in favour of the view that working hours of men should be reduced so that they can help their partners in nurturing kids and doing household tasks. Lights viewers condemned honour killing and compared to the heavy viewers the light viewers were more in favour of the view that honour killing must be stopped.

While looking at the responses given by heavy viewers, it was found that heavy viewers were more in favour of giving women equal rights as that of men to participate in household decision. A vast majority of heavy viewers considered subordination of women and prevailing system of rule of men mainly responsible for women's suffering in our society. They also supported the portrayal of women characters as assertive and capable of decision making. In the same way they stressed for equal pay scale and other benefits for working male and female staff in different organizations. They were also more in faovur of 
the view that women should be paid for household tasks. So it can be inferred that heavy viewers in some areas were favouring women's empowerment more than light viewers while in other areas they were less favouring it as compared to the light viewers .In some areas however, light viewers and heavy viewers both were in equal favour of women empowerment.

This shows that the time devoted in watching Star Plus soap operas did not have significant impact in changing the mind of people. This fact is also proved by the statistical analysis of Hypothesis 1 which argued that the heavy viewers of Star Plus soap operas will be more in favour of women's participation in national decision making process than light viewers. The obtained result did not support the research hypothesis as the calculated p-value exceeds 0.05 . So in the light of above results null hypothesis was accepted and research hypothesis $\mathrm{H} 1$ is rejected. The result shows that light viewers were more in favour of women's participation in national decision making process. The findings suggest that the difference in time devoted to watch Star Plus soap operas had no significant impact in changing the thoughts of viewers from Multan. It shows that heavy viewers of Star Plus were less likely to have their views regarding women empowerment influenced by television.

According to second Hypothesis that the heavy viewers of Star Plus soaps operas will be more in favour of women's equal educational rights than the light viewers. The findings approved the null hypothesis as the calculated p-value exceeds 0.05. So in the light of above results null hypothesis was accepted and research hypothesis $\mathrm{H} 2$ was rejected. The results showed that light viewers were more in favour of giving women equal educational rights than the heavy viewers.

Here again the findings suggest that time spent in watching Star Plus soap operas is not creating a big difference. So it can be inferred that time spent in watching in Star Plus soap operas did not have significant impact in changing the thoughts of people regarding women empowerment. The social and demographic factors tend to mediate the cultivation effects. So in this context local media should take serious steps and portray women in a manner that reinforce their constructive role.

Third Hypothesis argued that heavy viewers of Star Plus soap operas will be more in favour of government formulation of laws to protect women against violence than the light viewers. The findings from the data approved null hypothesis as the calculated p-value exceeds 0.05 . In this way, null hypothesis approved and H3 was rejected. Here once again it was proved by the finding that the time spent in watching Star Plus soap operas had no significant impact on the minds of viewers from Multan.

The overall, research revealed that ideology of Radical feminism was projected by Star plus soap operas by representing them stereotyped gender roles. Furthermore, the findings obtained from time wise analysis of survey questionnaire reveal that the time spent in watching Star Plus soap operas does not have great impact on heavy viewers in changing their minds and thoughts. It was found that heavy viewers in some areas were in favour of women empowerment more than light viewers but in other areas they were less in favour of it. Moreover in some areas light viewers and heavy viewers both were in equal favour of women empowerment.

This study will be very useful for other researchers who are interested in studying the impact of television in the lives of people. It will provide them with an excellent insight about the factors that mediate the cultivation process. Other researchers can apply the same study on Pakistani Drama and Soap Operas to check the portrayal of women by local media (in feministic perspective). The researchers can also analyze the same topic in the light of Social Expectation Theory and from other theoretical frame works. Moreover, same theoretical framework can be used to analyses the portrayal of females in Pakistani dramas.

\section{References}

Ahmed, A. (1991). “Women and Social Justice” Islamabad. Institute of policy Studies. 
Aslam, J. (2006) “Colorful Indian Marriage Ceremonies” retrieved from http://www.muslim-marriageguide.com/indianmarriage-customs.html on 03/05/2010.

Bowen, S., \& Wyatt, N. (1993). Transforming Visions: Feminist Critiques in Communication Studies, Cresskill, N.J: Hampton Press.

Bryant, J., \& Thompson, S. (2002). Fundamentals of Media Effects. NY. McGraw-Hill Companies Inc.

Karaj W., (2000). "Wonder Women: The Portrayal of Women in Television Soap operas".

Kaul, S ; \& Sahni, S. (2010). Portrayal of Women in Television serials, Stud Home Communication Sciences, 4(1):15-20 (2010) retrieved from http://www.krepublishers.com/02-Journals/SHCS/HCS-04-0-000-10-Web/HCS-04-1-000-2010-Abst-PDF/HCS-04-1-015-10-080-KaulS/HCS-04-1-015-10-080-Kaul-S-Tt.pdf

Kumar, H;\& V, J. (2005). Women's Empowerment. New Delhi Regency Publications,.

Mahwish, F, (2006). "Changing Life Style in Pakistan" retrieved from http://www.hamariweb.com/article.aspx?id=1168 on 12/05/2010.

Mustafa, G. (2006) "Revival of Pakistani Dramas" retrieved from http://www.thoughts.com/Roshni_com/blog/revival-ofpakistani-dramas-471805/ on 25/06/2010

Rahim, A. (1994). Impact of cable TV on television and video viewing in Hyderabad: A survey. Media Asia: An Asian mass communication quarterly, 21 (1), 15-20.

Shabir G, Safdar G, Imran M (2013) Cultural Effects of Urdu Dramas of GEO and HUM TV on women: A Case Study of Bahawalpur, Pakistan. The Women Annual Research Journal of Gender Studies.

Shoma M (2009). Prime Time Soap Opera on Indian Television, Routledge India.

Thornham, S. (2000). Feminist Theory and Cultural Studies. NY: Oxford University Press Inc.,

Wood, J. T. (1999). Communication, Gender, and Culture ( $3^{\text {rd }}$ ed). California: Wads Worth Publishing Company.

Wrye, K. H. (2009). The Fourth Wave of Feminism: Psychoanalytic Perspectives Introductory Remarks. Studies in Gender and Sexuality, 10(4), 185-189. doi: 10.1080/15240650903227999. 2009-1004. 